Supplement of Foss. Rec., 21, 237-284, 2018 https://doi.org/10.5194/fr-21-237-2018-supplement (C) Author(s) 2018. This work is distributed under the Creative Commons Attribution 4.0 License.

(c) (1)

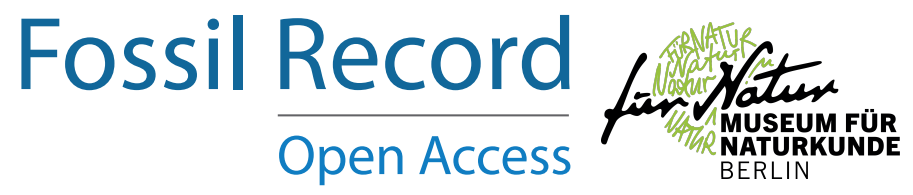

Supplement of

\title{
The turtles from the upper Eocene, Osona County (Ebro Basin, Catalonia, Spain): new material and its faunistic and environmental context
}

France de Lapparent de Broin et al.

Correspondence to: France de Lapparent de Broin (france.delapparent123@orange.fr)

The copyright of individual parts of the supplement might differ from the CC BY 4.0 License. 


\section{Supplement.}

S1. - Supplementary data on the compared European Paleogene Cheloniidae.

\section{S1(1) - Compared skulls of Argillochelys, Puppigerus and Eochelone.}

Several turtle taxa share the presence of a secondary palate, independently realized in different families. In sea turtles the maxillae and vomer are ventrally lowered behind the united premaxillae (in anatomical sense but “above” in ventral view) to form horizontal triturating surfaces below the level of the sulcus palatinus. The ventral part of the vomer is widened below the interchoanal pillar, and its ventral new face is inserted between the maxillae at their horizontal level. The anterior elongated part of the palatines that is also lowered at the level of the triturating surfaces, join the vomer. All of these parameters constitute a wide new rather horizontal triturating surface (just externally elevating to form the edge of the beak), and medially bordered by an edge all around and "above” (in ventral view) the medial sulcus palatinus. The foramina praepalatina disappear. In the sulcus palatinus, the inner choanae open on each side of the ventral interchoanal vomer pillar, both structures which become hidden when the vomer -palatine part of the palate increases. The palatine -vomer union characterizes the secondary palate of Cheloniidae. In a first approach, preceding the constitution of such a palate, the vomer -palatine contact is done by a single point, being still located on the lateral area inside the concave sulcus palatinus (e.g., see Toxochelys latiremis Cope, 1873 in Zangerl, 1953b), and the choanal openings and vomer pillar are still posteriorly well visible in ventral view. In the first derived state for the acquisition of this structure, the vomer is still ventrally slightly concave (i.e. the secondary palate is not completely flat medially) (such as in Argillochelys and Eochelone), and/or the suture vomer -palatine is (more or less) short. The most primitive known secondary palate in the North American Late Cretaceous Toxochelyidae s.l. is that of the lophochelyine 
length up to each fenestra subtemporalis) and the vomer is medially concave between the maxillae. A similar state is present in both the European early Eocene (Ypresian)

Argillochelys and middle Eocene (Lutetian) to upper Eocene (Priablonian) Eochelone (Casier, 1968; Moody, 1980; Lapparent de Broin et al., 2014; Owen and Bell, 1849). The secondary palate appears longer than in Ctenochelys in these taxa (i.e. comprising a little more than half of the palate length in the case of Eochelone) and with a slightly higher development in Argillochelys. However, in these taxa the maxilla -palatine suture is still short and particularly in E. brabantica. When the snout of the form is much more pointed, the triturating area is increased, as in the early Eocene (Ypresian) to middle Eocene (Lutetian) Puppigerus and as in the Maastrichtian Allopleuron. In Puppigerus the snout is anteriorly narrowed and it has a very long secondary palate, constituted together by the elongation of the snout in the area anterior to the palatines, and by the posterior enlarged area including a longer palatine -vomer suture (Moody, 1974; Owen and Bell, 1849). Thus, a long and narrow snout is present in this form, with the secondary palate medially reaching the transversal line passing at the anterior tip of the fenestrae subtemporales or staying close to this area. Lateroposteriorly, the triturating area integrates a part of jugals or/and pterygoids in P. camperi (Gray, 1831). A developed secondary palate is present in the living Cheloniidae (Carr, 1952; Gaffney, 1979) and in the extinct Euclastes group (see Jalil et al., 2009) that is longer than in Eochelone and Argillochelys, with a longer vomer-palatine suture. However, the palate of the living species is shorter than that of $P$. camperi, the palate not reaching the anterior tip of the ventral fenestrae subtemporales. The main differences comparing the palate of the Euclastes group with those of the living Cheloniidae consist of a few deep triturating surfaces, the softly inclined beak borders and no ridges in both the skull and the lower jaw. Besides, the snout is triangular and wide at its base (excluding the particular case of Erquelinnesia) and the palate is posteromedially, on each side, prolonged to cover the pterygoid processes (as in $P$. 
camperi). Contrarily, the external maxillary-premaxillary palate edge is more vertical and deeper in the living Cheloniidae and the pterygoid processes are posterior and even reduced posteriorly (Caretta, Chelonia). There are no upper or lower jaw ridges in the Euclastes group, and they may or may not be present in the living forms, depending on the species. The palate of the Euclastes group is also longer (more or less according to the species) than in the living Cheloniidae, reaching or posteriorly exceeding the transversal line corresponding to the anterior tip of the ventral fenestrae subtemporales. As in living species, the medial posterior extremity of the secondary palate covers two thirds of the palate length. However, as in Cheloniidae, the palate of the Euclastes group is anteriorly shorter than in P. camperi. The width of the snout of both the living Cheloniidae and the members of the Euclastes group is different for each genus, never being as narrow and long as in P. camperi. Other differences in the morphology of the secondary palate are recognized, when comparing other skull morphotypes of the Cheloniidae. For example, as far as the relative posterior length is concerned, the maximum length is reached by the Paleocene Erquelinnesia gosseleti (Dollo, 1886) from Erquelinnes and Bracheux (Oise, France, MNHN.F material mentioned in Lapparent de Broin, 2001). In this species, the palatines are united behind the vomer (precision about the data of Zangerl, 1971) and the secondary palate reaches the transversal line of the protruded oticus trochlearis process. The shape of the palate at the pterygoid processes also varies, showing different degrees of protrusion and reduction (Argillochelys antiqua (König, 1825) relative to A. cuneiceps (Owen, 1869) in Owen and Bell, 1869, various Euclastes species, living species) and more or less enlarging the palate.

Other skull characters are also very relevant for the differentiation of different clades, such as the patterns of the roof scutes (see the online supplementary data in Lapparent de Broin et al., 2014, and the information provided below). 
Argillochelys Lydekker, 1889 was erected on the skull of Chelone cuneiceps Owen, 1849 in Owen and Bell, 1849. Its holotype (NHMUK 41636) (previously BM(NH) 41636 in the literature) comes from the early Eocene (Ypresian) of the London Clay Formation (Warden Point, Isle of Sheppey, England). It was figured in Owen and Bell (1849; pl. 15: dorsal, ventral, lateral and posterior views) and Owen (1849-1884), with well figured and precise sutures and scute sulci, confirmed by the personal observation of the specimen, except for the frontoparietal scute, erroneously illustrated as not divided. The species has a characteristic scutation of the skull roof, including a single posterior parietal, posterior to the double frontoparietal scute (i.e. transversally divided). The posterior parietal is also single in Osonachelus decorata Lapparent de Broin et al., 2014b, but the shape of these scutes is not the same (Lapparent de Broin et al., 2014b; Owen and Bell, 1849). As indicated, contrary to the figure in Owen and Bell (1849), the frontoparietal of the Argillochelys cuneiceps (Owen, 1849) holotype is transversally divided, as in A. antiqua, Puppigerus camperi (Gray, 1831), Eochelone spp., Glarichelys gwinneri (Wegner, 1918), G. knorri (Gray, 1831), Euclastes spp. and the living species (with discrete frontal and parietal scutes in living forms; Brinkman, 2009; Carr, 1952; Zangerl, 1958). The most primitive presence of three posterior parietals in a transversal row, posterior to the transversally divided frontoparietal, is recognized in various Cheloniidae, including Argillochelys antiqua, Eochelone brabantica Dollo, 1903, and E. athersuchi (Moody, 1980), Puppigerus camperi, Glarichelys gwinneri and G. knorri (erroneously illustrated by two scutes in Zangerl, 1958, instead of three), Euclastes spp. and Tasbacka aldabergeni Nessov, 1987 (Casier, 1968; Jalil et al., 2009; online supplementary data in Lapparent de Broin et al., 2014b; Nessov, 1986, 1987; Owen and Bell, 1849; Wegner, 1911; Zangerl, 1958). However, it is not the case in the skull attributed to "Argillochelys" africana Tong and Hirayama, 2008 from the Moroccan phosphates (whose secondary palate morphotype is rather similar to that of an Euclastes group member). In this species, a 
rhombic frontoparietal is divided in four scutes, the last one posteriorly prolonged, constituting the medial scute of the three posterior parietals (online supplementary data in Lapparent de Broin et al., 2014b). The relative dimensions of the three posterior parietals is recognized as specifically variable considering all other taxa. For example, in the case of Glarichelys knorri in Zangerl, 1958, the median one is very narrow anteriorly, showing a pointed morphology, and acutely inserted in the raw, instead of primitively anteriorly as wide as the two other scutes. Only two posterior parietals are present in Trachyaspis, and the living genera Natator, Chelonia and Eretmochelys and this posterior parietal raw, as the lateral series, is subject to secondary multiplications in Caretta and Lepidochelys.

A skull from the London Clay is represented in plate 25 of Owen (1849-1884) and attributed to “Chelone” convexa Owen, 1842a (Owen, 1842b) (specific attribution identical to that of a shell figured in Owen and Bell, 1849, pl. 7; see main text and Tab. 2). It was figured together with the ventral view of a skull of "Chelone trigoniceps Owen, 1849" in Owen and Bell, 1849 the partial lower jaws of “Chelone longiceps Owen, 1842a” (Owen, 1842b) (its skull figured in Owen, 1879-1884 and Owen and Bell, 1849) and of “Chelone acuticeps Owen, 1849” in Owen and Bell, 1849, all of them being now recognized as synonyms of Puppigerus camperi (see Moody 1974). No shell is associated with the skull of $A$. cuneiceps. The attribution of the poorly preserved skull of "Chelone" convexa to Argillochelys cuneiceps is possible according to its ventral face, but not confirmed because the sulci of the roof scutes are poorly visible on the figure. Its attribution to the same taxon as the figured "C.” convexa shell (Owen 18491884, pl. 14; Owen and Bell, 1849, pl. 7) cannot be confirmed either.

The skull of "Chelone breviceps" Owen, 1842a (Owen, 1842b) was figured in the plate 1 of Owen and Bell (1849) (in dorsal, ventral, lateral and posterior views) and later (see Moody, 1980) it was referred to Argillochelys antiqua (König, 1825). Lydekker (1889b) figured the holotype of Chelone antiqua König, 1825 (NHMUK 49465) (previously BM (NH) 49465 in 
the literature), but the roof scutes are erroneously illustrated with a median postparietal that is united with the frontoparietal although correctly separating two postparietals. The posparietal scute series is also medially incomplete in the type of "C. breviceps" figured in Owen and Bell (1849) (pl. 1) contrary to the correct other figure of “C. breviceps” of Owen and Owen and Bell (1849) pl. 6, fig. 4 (where the sutures and scutes sulci in dorsal view were well shown) and also contrary to the MNHN.F skull of $A$. antiqua (see below). However, the two first skulls neverless agree with the presence of three postparietals in the fossil and not one as in the A. cuneiceps holotype. The Chelone breviceps i.e. A. antiqua skulls are all small in relation to A. cuniceps. “Chelone breviceps” was also figured by Owen and Bell (1849, pl. 2) with a carinated and tectiform carapace (pl. 2, fig.1) and narrow plastron, and the skull being associated to this plastron (pl. 2, fig. 2). Another skull was figured in lateral view (pl. 2, fig. 3). The juvenile shell of “Chelone latiscutata” Owen, 1842a (Owen, 1842b), now recognized as a juvenile Puppigerus camperi specimen, was also included in plate 6 of Owen and Bell (1849) with “C. breviceps” Owen, 1872a (Owen, 1842b). Owen (1849-1884) also figured a shell and two skulls of “C. breviceps” (pl. 16, 17, and 17A) in several views. All skulls and shells of "C. breviceps” and the referred species "C. subcristata” Owen, 1842a (Owen, 1842b) and "C. subcarinata” Owen, 1849 in Owen and Bell, 1849 presented in the above indicated plates of Owen (1849 -1884) and Owen and Bell (1849) are now attributed to A. antiqua, this species being the senior synonym (Moody, 1980). Argillochelys antiqua was figured with a rather rounded-trapezoidal snout and with a wide external naris, whereas the most anterior region being unknown. The personal observation of this taxon shows that it was more pointed anteriorly, justified by the rather pointed figured lower jaws and the absence of a premaxillary tip in the figured specimens. The lower jaw of the holotype is not separated from the skull, and the anterior palate is not prepared. But it is possible to characterize the skull by characters corresponding to other areas, among which the whole external shape, the 
orbit size, the interorbital space and the characteristic pattern of scutes with three posterior parietals. All these features differ from those of A. cuneiceps. Another specimen corresponding to this form is an unpublished partial skull from Sheppey (MNHN.F CGB 4, from an old but not specified collection). Its small size is similar to that of the holotype. This skull conforms in shape with that of the figures of "C. breviceps" (i.e. A. antiqua) of Owen and Bell (1949), including the pattern of scutes of skull roof and the morphology and development of the palate. The snout of MNHN.F CGB 4 is slightly more complete than in Owen’s figures, being anteriorly pointed (although also having an incomplete premaxillary tip), and enough pointed to be compatible with the previously referred lower jaw figured by Owen (1849-1884). Its ventral palate is also better visible than that in Owen and Bell (1949). Thus, the palate of the skull types of the two Argillochelys species can be compared. They are recognized as clearly distinct but similar in the secondary palate. The size of the holotype of A. cuneiceps is slightly larger than that of this C. breviceps (i.e. A. antiqua) skull (20 to 33 \%). This might be interpreted as an individual variation, but all the "C. breviceps” skulls are smaller. Ventrally, the skulls of both species present a short secondary palate, with narrow palatine borders medially along the maxillae up to the vomer. In A. cuneiceps the ventral face of the vomer participates in the secondary palate and is at the level of the maxillae and palatines. However, it is medially slightly concave, and the choanae are barely visible on each side of the vomer pillar extremity, which are also barely visible as in A. antiqua. A longer union of the vomer with the palatine, a relative wider vomer at midlength, and the more separated and acutely protruding pterygoid processes are recognized for $A$. cuneiceps. Dorsally, the number and shape of the scutes are different between both species, as seen above. The median posterior extremity of the secondary palate of both species is well anterior to the location of the ventral fenestrae subtemporales, being situated between the mid length and the third of the palate length. 
175 The type species of the genus Puppigerus Cope, 1871 is Emys camperi Gray, 1831, from the

176 “Emydes de Bruxelles” and "Emydes de Sheppey” in Cuvier (1824) (see all details in Moody,

177 1974, and figures of “Chelone longiceps” Owen, 1842a, in Owen, 1849-1884, and Owen and

178 Bell, 1849 principally, see the main text). Puppigerus camperi is recognized here by both the

179 middle Eocene (Lutetian) Belgian type series (including the shell holotype), and the early

180 Eocene (Ypresian) London Clay material. It is not compared with other specimens attributed

181 to the species in the world such as the Moroccan Paleogene specimen (Tong et al., 2012). P.

182 camperi is well characterized by several anatomical characters relative to Argillochelys:

183 anteriorly narrow elongated skull; long pointed snout, in association with a long secondary

184 palate; secondary palate with elongated maxillae and premaxillae, relatively long vomer, wide

185 palatine surface; jugal participating in the palate and also forming an important region of the

186 pterygoid processes, which are also (anteriorly) involved in the secondary palate structure;

187 and longer ventral subtemporal fenestrae, between the processus trochlearis oticus and the

188 jugal. The vomer-palatine suture length of $P$. camperi specimens is individually variable. It is

189 as long as in Argillochelys in some individuals but generally longer. The transversal distance

190 between both perygoid processes is lower than in Argillochelys cuneiceps and the median

191 width of the united narrow pterygoids is relatively lower than in A. antiqua, being as narrow

192 as in E. brabantica. The vomer pillar and the posterior extremities of the choanae are

193 completely obscured by the ventral contact of the long vomer and the palatines. The palate of

194 P. camperi is longer than that of the living Cheloniidae. Its palatines are not as long as those

195 in the Paleocene Erquelinnesia gosseleti (Dollo, 1886) palate. In addition, they are not

196 medially united behind the elongated vomer (as seen above), a character identified as an

197 autapomorphy for E. gosseleti. Therefore, the choanae of $P$. camperi are anterior to those of

198 E. gosseleti and located at the level of the anterior border of each fenestra subtemporalis. This

199 contrasts with the much more posterior position in this second form, where they are close to 
the level of the processus trochlearis oticus. The $P$. camperi pattern of dorsal scutes is the most frequent for Cheloniidae, showing three posterior parietals as in A. antiqua, and not only one as in A. cuneiceps and Osonachelus. This relatively primitive morphotype with three parietals is also present in Eochelone, but the parietals of $P$. camperi are relatively longer with the medial scute length being ca. 3/4 of that of the lateral, instead of 1/2 in Eochelone brabantica and ca. 4/5 in A. antiqua. In the revised P. camperi specimen IRSNB R75 (Reg 16), the frontoparietal scute is recognized as transversally divided, contrasting with that in the figure of Owen and Bell (1849: pl. 3, fig. 2). In addition, it is separated from the posterior medial parietal, contrary to the disposition in the figures of Owen and Bell (1849: pl. 3, fig.2) and of Moody (1974: pl. 3C). Thus, these scutes are separated as in other P. camperi specimens and other "Eochelyines”. In this sense, the medial posterior parietal of IRSNB R 76 (Reg 18, IG 19779) is also separated from the transversally divided frontoparietal as figured in Moody (1974: pl. 3B).

The skull of Eochelone brabantica is recognized as different from those of Argillochelys and $P$. camperi by the different skull roof scutes, its greater size and the more domed dorsal roof part, with the lateroanterior borders converging in an elongated snout that is almost as long as the snout of $P$. camperi. However, its skull is narrower anteriorly in relation to its width posteriorly to the orbits and is not ventrally elongated between the processus trochlearis oticus and the anterior border of each ventral fenestra subtemporalis. The distance between the processi pterygoidei is large while the minimal width of the united pterygoids is small. Anteriorly, the premaxillae point below the dorsal border of the nostril, as can be observed in both dorsal and lateral views. As in Argillochelys, the secondary palate of E. brabantica is posteromedially short. Thus, its palatino-vomer suture is short, with very narrow palatine borders medially sutured to the maxillae and overhanging the palatine sulcus. The palatine borders of this form are narrower than those of Argillochelys cuneiceps and A. antiqua 
Ventrally, parts of the choanae and the interchoanal pillar of the vomer of E. brabantica are visible. The ventral surface of the vomer is medially slightly concave. The vomer is not medially at the level of the maxillae and palatines and extends not enough posteriorly to cover the posterior extremity of the choanae, as in Argillochelys. The palatines of E. brabantica are not medially sutured behind the vomer, as in Argillochelys and P. camperi, in contrast to the Paleocene Erquelinnesia gosseleti. The secondary palate of E. brabantica is poorly developed, as in Argillochelys, but its skull is dorsolaterally more rounded. The secondary palate is a little less developed in length than in Allopleuron hoffmanni (Gray, 1831) (whose skull appears longer because of its elongated anterior snout) and probably Osonachelus decorata, but, as in Argillochelys, it is markedly less developed than the strong secondary palate of $P$. camperi and that of the Euclastes group (including Tasbacka aldabergeni), Erquelinnesia gosseleti and the living Cheloniidae (see figures in Carr, 1952; Gaffney, 1979; Wyneken, 2001). The lower jaw of both Eochelone brabantica and Osonachelus decorata was recognized as particularly modified relative to other Cheloniidae, showing a concave, narrow, inclined and smooth "triturating” surface for a snatching beak, in contrast to the morphotype with flatly dilated surfaces corresponding to a hard prey crushing diet, animals and vegetables included (Casier, 1968; Lapparent de Broin et al., 2014; Parham and Pyenson, 2010). Instead, these adaptations possibly facilitated a vegetarian cutting feeding pattern or a feeding pattern of soft preys.

\section{S1(2) - Compared shells of Argillochelys, Puppigerus and Eochelone.}

Owen and Bell (1849) presented three tectiform, more or less acutely carinated carapaces from the early Eocene (Ypresian) of the London Clays, which are attributed here to Argillochelys antiqua. A. antiqua has a carapace only known by the costal disk and a narrow part of the anterior border. It has narrow fontanelles lateral to the posterolateral border of the 
nuchal and to the costals, between the short free thoracic ribs. All known shells attributable to this form are of small size: there are those originally presented as “C. breviceps" (Owen and Bell, 1849, pl. 2, an incompletely mature animal, i.e. between more juvenile and older grownup adult - for which ca. $18 \mathrm{~cm}$ of maximum length of the shell are interpreted based on the 14 cm preserved), “C. subcristata” and “C. subcarinata” (both being slifhtly flattened, the maximum length of the shell being estimated as 25 and $27 \mathrm{~cm}$ respectively, 23 and $25 \mathrm{~cm}$ being preserved). The elbowed peripherals 1 recognized for this taxon are only preserved in the specimens of "C. breviceps" and "C. subcristata". All the shells attributed to A. antiqua lack the peripheral border from the second ("C. breviceps" and " $C$. subcristata") or first (“ $C$. subcristata”) peripheral up to suprapygals 1 and 2. Only one of the plastra has the epiplastra fully preserved (i.e., the specimen of "Chelone subcarinata”). The smaller specimen (i.e., the shell with skull of "C. breviceps", shown in pl. 2 of Owen and Bell (1849) is recognized as the younger individual. It shows the longest proportion of free costal ribs, and has the widest vertebrals, pinched at the junction with the intercostal sulci. The two larger shells have narrower vertebrals 2 to 4, with more parallel lateral borders, the fourth being posteriorly narrowed. The dorsal disk of the two latter shows an advanced degree of ossification. The carapace is narrow for its length, relatively narrower than the carapace of Puppigerus camperi (Moody, 1974). The thickness of their bones shows the adult state. An acute carina, at least medioposteriorly developed, is present in the tectiform carapace of this form. Argillochelys antiqua has larger lateral and longer central plastral fontanelles than P. camperi, even considering the young individual IRSNB R 80 (IG 8632) of the latter species (18 cm long). However, the fontanelles of the three specimens of $A$. antiqua are noticeably relatively smaller than those of E. brabantica and E. voltregana n. sp. (Tab. 2). The shells previously attributed to "Chelone subcristata" (see pl. 8 in Owen and Bell, 1849, a carapace with plastron from Sheppey) and “Chelone subcarinata” (see pl. 8A in Owen and Bell, 1849, a 
carapace with plastron from Harwich) conform to that of "Chelone breviceps", with some individual differences, beside the more adult size and state. All these shells are considered as attributable to A. antiqua by their similarity with the shell in the associated skull - carinated carapace of “C. breviceps”, conform to the holotype of König (1825). Several minor differences are recognized by comparing all these specimens. Thus, the quadrangular neural can be in first or second position, the carina is more or less continuous, with or without neural dorsal protrusions, and the length to width ratio of the vertebrals is variable. The proportion of the dorsal and plastral fontanelles proportions in A. antiqua differ from those in E. brabantica, E. voltragana n. sp. and of P. camperi (see Tab. 2). The adults of A. antiqua are always smaller than in these forms.

Another specimen from the London Clay, MNHN.F CGB43 - AC 8362, was identified as “Emyde de l’Isle de Sheppey” by Cuvier (1824, pl. 15, fig.12). The specimen corresponds to a partial carapace. As Cuvier (1824, p. 234) indicated, it is a fragmentary costal disk of $14 \mathrm{~cm}$ length, preserving the costals 2 to 7, and the corresponding neurals. Neural 2 is hexagonal, with short anterolateral sides (indicating the first neural was quadrangular). The shell is tectiform, being slightly laterally compressed. The maximum height of the preserved region is $6 \mathrm{~cm}$, the width of the pleural disk is $13 \mathrm{~cm}$. Medially, costals 6 posteriorly contact the pentagonal neural 6 and anteriorly neural 7. Fine radiating ridges of the vertebrals are present. The shape of the vertebrals conforms those of "C. subcarinata" and "C. subcristata" (i.e., the adult specimens of $A$. antiqua), but it can also represent $A$. antiqua by its narrow carinated tectiform shape and its small adult size. However, the medial contact of costals 6 is present only in that specimen. A medial contact of the costal series is rarely present in Cheloniidae, but it is known in "Carettiine” living Cheloniidae (see Sect. S3). The specimen is interpreted as a representative of $A$. antiqua, and this allows to increase the knowledge about the individual variation in this species. 
Owen and Bell (1849) figured two other London Clay shells, not carinated (unlike

302

303

Argillochelys antiqua) and with a quadrangular second neural. One of them, from Sheppey, was attributed to a species named “Chelone” convexa Owen, 1842a (Owen, 1842b) (in Owen and Bell, 1849, pl. 7). The other, from Bognor (Sussex) was designed as "Chelone" declivis Owen, 1849 in Owen and Bell, 1849 (pl. 14). They cannot be attributed to A. antiqua, Puppigerus camperi or Chelone planimentum Owen 1842a (Owen,1842b) - C. crassicostata Owen and Bell, 1849 (i. e. Glossochelys planimenta in Zangerl, 1971).

On the one hand, “C.” convexa is represented by the costal disk and the plastron of a young individual, with an estimated carapace length of $16 \mathrm{~cm}$. Its carapace is flattened, just roundly medially pointing, lacking an acute carina. Its poorly-preserved plastron shows fontanelle proportions close to those of Eochelone, by the central pentagonal fontanelle, differing from those of A. antiqua and Puppigerus camperi. However, this specimen has a second quadrangular neural as in "C. subcristata" (attributed to A. antiqua), and in the specimen of Puppigerus from the London Clay named “C. longiceps” by Owen and Bell (1849, pl. 5). This latter specimen, from the early Eocene, is the only Puppigerus camperi shell with this configuration and five middle Eocene specimens deposited in the IRSNB are known without this feature. The young individual attributed to "C.” convexa has relatively wider vertebrals than Eochelone spp., "Chelone subcristata”, “C. subcarinata” (for A. antiqua) and Puppigerus camperi. In addition, it lacks the rounded and cordiform costal disk present in this latter form.

On the other hand, “Chelone” declivis is represented by a portion of a costal disk of $18.2 \mathrm{~cm}$ length (the maximum length of the complete carapace is estimated as $26 \mathrm{~cm}$ ). It corresponds to an elongated not carinated form. It has been flattened as a result of postmortem processes. As indicated, this specimen also has a quadrangular second neural. The question is if one of 
these two forms could belong to A. cuneiceps. They lack an acute carina, as Puppigerus camperi, but differ from this form by the weaker ossification degree, especially in the case of the small "C." convexa, which differs from the smallest Puppigerus camperi carapaces (figured in Moody, 1974 and Owen and Bell, 1849). The size of both specimens is compatible with that of the adult individuals of Argillochelys antiqua, being significantly smaller than those of Puppigerus camperi and Eochelone spp. The position of the first quadrangular neural is recognized as variable for the early Eocene species from the London Clay Formation. Considering all the previously given information, the attribution of " $C$." convexa (skulls and shells, Owen, 1849-1884) to A. cuneiceps is possible. By its shell, it differs from Eochelone voltregana n. sp. by its more juvenile shape and its quadrangular second neural, but by its fontanelles it is more similar than to Argillocheys antiqua.

Beside the specimen that can be attributed to Argillochelys species, Owen and Bell (1849) also figured several specimens from the London Clay (from both Sheppey and Harwich) that belong to Puppigerus camperi (including the "Chelone longiceps" and "Chelone latiscutata" in part shells) (see Moody, 1974). Owen and Bell (1849) also figured three large and narrow carapaces of Glossochelys planimenta (see Zangerl, 1971), and two skulls of this form, from the early Eocene (Ypresian) of Harwich (i.e., “Chelone” planimentum in Owen and Bell, 1849, pl. 9, 10 and 10A; and "Chelone crassicostata" in Owen and Bell, 1849, pls. 1 and 12). Moody (1980) differentiated them from Neurochelys harvicensis (Woodward, 1830) but this is not clearly established. The skulls are recognized here as related to those of Erquelinnesia gosseleti from Belgium (see Lapparent de Broin, 2001), but they have not been thoroughly prepared, especially considering their palates, so that their attribution to the same genus cannot be confirmed. They were not figured by Moody (1980), but he proposed them as representatives of “Erquelinnesia planimenta (Owen, 1841)”. He introduced Erquelinnesia gosseleteti (Dollo, 1887) as a junior synonym, recognizing the priority of Erquelinnesia for 
the genus of this species (rejecting the name of Glossochelys Seeley, 1871 as a junior synonym of Neurochelys). This proposal was done only based on measurements, without preparation of the palate and not discussing the morphological characters, and not considering the temporal difference between the English and Belgian forms. Thus, this proposal stood in contrast to the opinion of Zangerl (1971). In the meantime, it became evident that these shells (above mentioned) present characters shared with the toxochelyids and members of the Euclastes group (given above). These shells are compatible with the Belgian Erquelinnesia gosseleteti morphotype, although the presence of nuchal fontanelles, present in this Belgian form (see Zangerl, 1971, pl. 7), cannot be seen in these English shells. Without the preparation of the London Clay specimens, especially those of the skulls, its possible synonymy or close phylogenetic relationship with the Belgian Erquelinnesia gosseleti cannot be evaluated. Other specimens of “C. crassicostata” in Owen and Bell (1849, pl. 13) belongs to Puppigerus camperi and all those materials differ from Eochelone spp.

Adult Puppigerus camperi specimens are identified from both the early Eocene (Ypresian) London Clay and the middle Eocene (Lutetian) Brabant province. The maximum length of the shell of these fully ossified adults is $51.5 \mathrm{~cm}$, the larger specimen corresponding to the lectotype, i.e. the Belgian individual IRSNB R4. The synchronous and sympatric presence of both Puppigerus camperi and Eochelone brabantica is recognized in several Belgian localities of the Brabant province. In contrast to Eochelone spp., the carapace fontanelles of Puppigerus are almost closed, at an age presumably corresponding to that of the adult carapaces of Eochelone (up to 50 to $63 \mathrm{~cm}$ carapace long) preserving the fontanelles. It also has a massive adult plastron, with a small central fontanelle, much reduced lateral fontanelles and the absence of a xiphiplastral fontanelle. Thus, the osseous elements composing this plastron are relatively wide, and the borders of the lobes are rounded. In fact, the carapace is 
375 wider relative to its length than in the other species. The reduction of the primitively

376 hexagonal first neural (being also known at least in one individual of Toxochelys barberi

377 Schmidt, 1944 figured in Zangerl (1953b)) to a quadrangular plate appears to be common in

378 Cheloniidae and other families. The position of the quadrangular neural is not fixed in

379 Puppigerus camperi (as in A. antiqua, as seen above). Neural 1 is visible in five specimens

380 from the Lutetian of Brabant belonging to the IRSNB collection. The lectotype (IRSNB R4,

381 Reg 1687) corresponds to an adult from Melsbroek, with a carapace length of $51.5 \mathrm{~cm}$. The

382 first and the second neurals of this specimen, and also of IRSNB R78 (from Vieux Genappe)

383 are pentagonal. The first neural of the other three specimens (IRSNB R72 and IRSNB R73,

384 from an unknown locality, and IRSNB R79, from Maransart) is quadrangular. One specimen

385 from the Ypresian London Clay of Sheppey (C. longiceps in Owen and Bell, 1849, pl. 5) has

386 the first neural that is hexagonal posteriorly short sided (i.e., sharing the primitive condition),

387 the quadrangular neural being the second. The arrangement in Puppigerus camperi in which

388 the first and second neurals are alternatively pentagonal (IRSNB R4 (Reg 1687) and IRSNB

389 R78) is shared with the holotype of Osonachelus decorata (Fig. 10 (f1) (f2)) and by one

390 individual of Toxochelys moorevillensis Zangerl, 1953b. Thus, the quadrangular neural of all

391 these taxa preserved as positioned in the first position is not fixed. This feature consisting of

392 the presence of two or three states together in a species (the quadrangular neural being located

393 in the second place, or the presence of first and second pentagonal neurals, or the first neural

394 in first position) is unknown in post-Lutetian Cheloniidae, being in particular also unknown

395 for Eochelone spp.

397 Eochelone brabantica (Fig. 7) (Casier, 1968; Gaffney,1979; Hirayama, 1995; Zangerl, 1980),

398 also from the middle Eocene Bruxellian (Lutetian) of the Brabant province, is represented by

399 eleven IRSNB specimens, including the three skulls figured by Casier, 1968 and the 
400

401

402

403

404

405

406

407

408

409

410

411

412

413

414

415

416

417

418

419

420

421

422

423

specimens mentionned by Dollo (1903) (“Reg” numbers): 1) The holotype, IRSNB R1 (Reg 1661), from Saint-Remy-Geest. A partial skeleton including the partial shell, arranged on a metal structure (ca. 55 to $63 \mathrm{~cm}$ long) (Fig. 8 (a), the skull and the lower jaw (Fig. 8 (a7)) (Dollo, 1903; Casier, 1968, pl. 2). 2) IRSNB R61 (Reg 1688), from Loupoigne, skull (Fig. 8 (b) and shell (Fig. 9 (c)) (63 cm long) (Dollo, 1903; Casier, 1968, pl. 3, 4). 3) IRSNB R62 (Reg 3907), from Loupoigne, longitudinally sectioned skull (Dollo, 1903; Casier 1968, pl. 5). 4) IRSNB R339 (Vert 00000-1691, Reg 1691), from Loupoigne, shell with carapace and plastron (Fig. 9 (a)) (50 cm long) (Dollo, 1903). 5) Vert-00000-01692 (Reg 1692), from Loupoigne, dissociated large carapace $(>50 \mathrm{~cm}$ ) with plastral and limbs elements (Dollo, 1903), from Loupoigne. 6) IRSNB R340 (Vert-18733-01662, Reg 1662), from Melsbroek, partial carapace, costal disk and anterior peripheral border (ca. $50 \mathrm{~cm}$ long) in ventral view, Dollo, 1903) (Fig. 9 (b)). 7) Vert-00000-01693 (Reg 1693), from Brabant (Nivelles?), a shell (Dollo, 1903) (52.4 cm long) visible in dorsal view. 8) Vert-08289-00011, from Plancenoit, mid-posterior part of a young costal disk with costals 4 to 8 with wide free ribs, neurals and suprapygals 1 and 2 (ca. $22.5 \mathrm{~cm}$ long preserved) of a carapace (more or less eroded) in dorsal view. 9) Vert-08457-00001, from Maransart, elements of the peripheral border with some neurals and costals of a dissociated shell (ca. $28 \mathrm{~cm}$ wide preserved disk) visible in dorsal and ventral views. 10) Vert-08487-03907, Maransart-Plancenoit, pairs of costals 2, 3, 4, with wide free ribs and corresponding neurals (34 cm wide preserved disk), in dorsal view. 11) Vert-08457-00002, from Vieux-Genappe, young carapace (15 cm long) poorly ossified, in ventral view.

(S1(3) - Summary of some specific features of Eochelone voltregana $n$. sp. in relation to the members of the Eo-Oligocene group. 


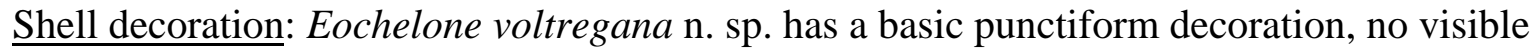
surface bone microdecoration or reticulation by anastomosed sulci in polygons (reticulation represented in drawings of $A$. antiqua specimens), and no radiating vertebral stripes (present in E. brabantica), or no stronger carapace decoration by granulation and ridges (Glarichelys gwinneri and G. knorri) (Fig. 11). Shell shape: Eochelone voltregana n. sp. is similar to Glarichelys (G. gwinneri and G. knorri) in its ovorectangular carapace shape. The carapace is not as posteriorly pointed and not widened and rounded at mid length as in E. brabantica and Puppigerus camperi. Eochelone voltregana n. sp., E. brabantica, Puppigerus camperi and Glarichelys differ from Argillochelys antiqua by their larger adult size, a broader carapace

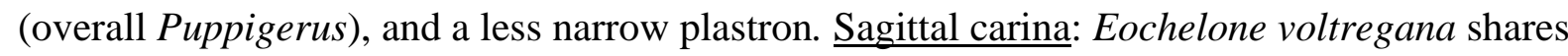
with P. camperi and most Eochelone brabantica specimens the absence of an adult sagittal carina, unlike one E. brabantica specimen (with one weak posterior carina), and unlike all A. antiqua specimens (“C. breviceps”, “C. subcarinata” and “C. subristata” specimens) which have a tectiform carapace, and also unlike "C.” convexa which has a carapace with an ogival transversal section, “tectiform” but without an acute angle. Adult fontanelles: Eochelone voltregana n. sp. shares with E. brabantica and Glarichelys an adult carapace remaining with a greater perimeter of lateral fontanelles, and an adult plastron with well defined and relatively larger fontanelles (ento-hyoplastral, central hyo-hypoplastral, probable narrow inter-xiphiplastral, and lateral fontanelles). The fontanelles are wider than in A. antiqua and overall P. camperi, the latter particularly differing by its small narrow, oval central fontanelle, smaller triangular or narrowly rectangular lateral fontanelles, and absence of xiphiplastral fontanelles, in a plastron with more rounded lobes. Entoplastron: Eochelone voltregana n. sp. shares with E. brabantica, A. antiqua and Glarichelys the entoplastral lateral borders of the anterior interclavicule body which are not or barely incurved, not forming lateral wings in the ento-hyoplastral fontanelle, which the entoplastron fills only partially. It differs from $P$. 
camperi in which the entoplastron is massive and the hyo-entoplastral fontanelles are nearly filled. First quadrangular neural: Eochelone voltregana n. sp. has the first neural that is quadrangular and neurals 2 to 7 are hexagonal with anterior lateral sides, as some A. antiqua and some $P$. camperi specimens, but unlike, on the one hand, some other A. antiqua specimens (where the second neural is quadrangular in specimen "Chelone subristata”), “C.” convexa (possible synonym of $A$. cuneiceps?) and one $P$. camperi specimen, and, on the other hand, unlike $P$. camperi s lectotype where neurals 1 and 2 have alternatively five sides. Suprapygals: Eochelone voltregana n. sp. shares with E. brabantica, Glarichelys and some specimens of $P$. camperi the number of three suprapygals (only two in some $P$. camperi specimens but filling the complete space between the costals 8 in all the specimens) (unknown in Argillochelys). Thoracic rib 9: Eochelone voltregana n. sp. differs from E. brabantica, some specimens of P. camperi, Glarichelys gwinneri and G. knorri by the straight thoracic rib 9, below costal 8, which corresponds with the suture between peripherals 10-11, and not with peripheral 11 alone (as it occurs in those taxa in which rib 9 is curved) and thoracic rib 8 is also straight, which corresponds with the suture between peripherals 9-10, i.e. there is no peripheral 10 without a free rib contact, contrasting with some Puppigerus and Glarichelys knorri specimens (unknown in Argillochelys). Humerus: Eochelone voltregana n. sp. humerus conforms to that of E. brabantica and P. camperi but is more robust (unknown in A. antiqua and adult Glarichelys).

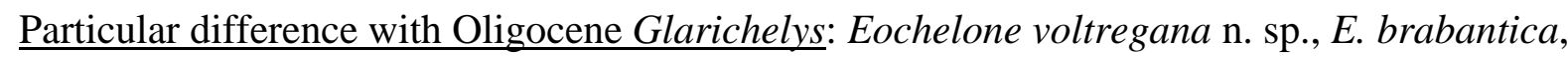
A. antiqua and Puppigerus camperi differ from Glarichelys gwinneri (that is an adult specimen)and G. knorri (that is composed of juvenile specimens) by the absence of a marginal posterior sinuosity and of strong ornamentation; from adult G. gwinneri alone by a much narrower main part of the plastron with a narrower central fontanelle, a much narrower 
473 hyo-hypoplastral suture and relatively narrower lateral notches in proportion to the central 474 fontanelle.

475

S1(4) - Comparisons of Cheloniidae of the middle Eocene (Lutetian) of Avesa (Italy).

477 The stratigraphical position of Avesa is equivalent to that of the sites where the specimens of 478 Eochelone brabantica were found and close to that of E. voltregana n. sp. The Cheloniid from 479 Avesa studied here corresponds to an indetermined taxon identified by an unpublished specimen (MHNV V2342-V2345) (see Avesa in Broin (1977)) that might be related to "Eochelyines” by its size. Other turtles from this locality, corresponding to Pelomedusoides (Pleurodira) are examined in Sect. S3 (2a, b, c), being compared to the Taradell specimen of Podocnemididae. Besides, another indetermined Cheloniid represented by large and distinct specimens from those examined here are identified in the same Avesa MHNV collection. They include a skull mold (V2349)) and partial shells (V 2384 and V 2385) as briefly mentioned in Broin (1977).

MHNV V2342-V2345 consists of an incomplete carapace specimen, which is preserved as both the external and the internal casts, but also preserving osseous remains. The maximum length of the preserved region is about $30 \mathrm{~cm}$, the maximum width is close to $22 \mathrm{~cm}$. One of the two slab sides shows the costals imprint, and osseous remains corresponding to the remaining proximal and medial region of the costals, and the partial neurals 1 to 3 , and the complete neural 4. The carapace was oval and wide, and not cordiform. It was nearly fully ossified with narrow lateral carapace fontanelles. The internal cast shows that the relatively short costal 1 was sutured to a wide nuchal and widely to the peripheral 1 and possibly also in contact with peripheral 2 in contrast to Eochelone voltregana n. sp. This costal 1 was lateroposteriorly free of sutures. The cast shows the preserved posterior border of the nuchal, medially bearing a part of the rhombic cheloniid knob scar for the $8^{\text {th }}$ cervical, which was 
shorter and rounder than in Eochelone brabantica (Fig. 9 (b)). The internal cast of the ventral surface of costal 1 does not reveal the precise morphology of ribs 1 and 2, but an erosion mark corresponds to them. Thus, rib 2 is recognized as transversal along the plate, lacking an axillary buttress mark. This conforms to the clade Cheloniidae. The position of the peripherals is barely perceptible on the matrix, not being far away from the lateral extremity of the cast of the costals on the left preserved side. Costals posterior to costal 1 and peripherals are not sutured. These costals are wide for their length and for the neural width, which agrees with a relatively well-ossified carapace, but retaining lateral fontanelles. Indeed, the preserved lateral extremity of left costal 5 allows recognizing the narrow lateral fontanelle, based on the relatively narrow space between the costals and the peripherals. The lateral free ribs extremities that exceed the dermal bone of the costals form an important and rounded lateral protrusion, as in the other members of Cheloniidae. The neurals are moderate in size, being relatively wider than in Eochelone with respect to their length. The first one is ovoquadrangular and the following are hexagonal, with their short sides being anterolateraly located. They constitute a continuous series composed by nine neurals, from the nuchal to a trapezoidal region corresponding to the suprapygals 1 and 2. The mid-posterior preserved area of neural 2 presents fine longitudinal stripes narrowly radiating. The preserved neural 3 (crossed by the transversal intervertebral sulcus V2-V3), and the preserved costals 5, 6 and 8 (crossed by the intervertebral sulcus V4-V5) have a dense outher surface, composed by minute pores. On the other slab, the disjointed medial part of costal 5 (with the sulcus junction of vertebral 4 with the pleurals 3 and 4 ) has weak elongated and dichotomized sulci. This cast shows in several places a network composed by very small polygons, which correspond to the median lacunar layer of the sectioned bones. It does not correspond to a decoration by a granulous external bone surface as, for example, in Glarichelys winneri. A finely granulated sansdstone matrix, distinct from this inner dermal bone layer is recognized between the plates 
523 and their imprints. This Cheloniid is too poorly preserved to be named or phylogenetically

524 located in relation to Eochelone. But it does not belong to Eochelone because of its stronger

525 ossification, costal 1 contact with peripheral 1 and wider neurals in relation to their length. It

526 does not correspond to Puppigerus either, as indicated by its ossification degree and shape

527 and the relative greater length relative to its width.

S2 - Data on the skulls of Trionychinae: Trionyx s.l. differentiation

530

531

532

533

534

535

536

537

538

539

540

541

542

543

Trionyx s.l. represents the Western European lineage to which the living Trionyx triunguis belongs. This species has a skull neither particularly narrow nor wide relative to other groups of Trionychinae, with a rather pointed snout. Furthermore, the orbit length is greater than the external naris-orbit distance, which is longer than the interorbitary space, which, in turn, is longer than the postorbital arch between the orbit and the fossa temporalis superior. The palate is characterized by: 1) a moderatly sized foramen intermaxillare which is shorter than the palatal suture between the maxillae and longer than the relatively small choanae, resulting in a rather long distance between the foramen intermaxillare and the choanae. 2) the sulcus palatinus morphology that is characterized by the presence of medially joined maxillae that obscure ventrally the vomer (with specific variable details in the vomer coverage, as explained below). Thus, the vomer is not ventrally exposed posterior to the foramen intermaxillare, between the maxillae, contrary to that of the living Rafetus and Apalone (senior synonym of Platypeltis) (Broin, 1977, figs. 67 and 68) and it only appears posteriorly, in the upper plan, between the choanae. The sulcus palatinus has a variable depth in Trionyx s.l. Its margins are externally limited by a crest and its borders remain separated from the choanae. The borders of the external sulcus are parallel along its anterior part, but they diverge posteriorly. The lower jaw symphysis is long relative to both the length of the snout and the distance between the foramen intermaxillare and the choanae (Broin, 1977, fig. 31, 
548 pls. $7(3,4), 11)$. The Paleocene to Pliocene species sharing all these characters show

549 differences in the way the left and right maxillae are joined below the vomer. We opted for

550 the use of Trionyx s.l. for all the specimens sharing the same features exposed above, despite

551 some differences exposed below, but together sharing shell characters also present when the

552 skull is not known. Actually, some of the few fossil European species known by the skull

553 differ in the medial sulcus morphology which might be the base of a generic subdivision. The

554 sulcus has a U-shape in section in the indetermined Paleocene species from the locality of

555 Mont de Berru (Marne, France) (Broin, 1977, fig. 71; and new unpublished material) as in the

556 early Ypresian form from Avenay (Marne, France) (see Broin, 1977) (MNHN.F collection. A

557 widely less deep obtuse V-shape is present in the known skulls from the other localities

558 (Broin, 1977). The joined maxillae of these last species form a medial double and narrow

559 sulcus in the medial line of the palate, where these bones cover the vomer. Thus, the common

560 suture of the maxillae is visible in a narrow longitudinal sulcus forming a longitudinal strip

561 between the more ventral maxillae borders of the main sulcus. In Trionyx silvestris Walker

562 and Moody, 1974, from the lower Eocene (early Ypresian) of England, this thin maxillary

563 strip is well visible, being as wide as the vomer pillar which appears posteriorly between the

564 choanae. The two ventral margins of the main sulcus are closer to each other and nearly join

565 in Trionyx michauxi, Broin, 1977 from the early Eocene (late Ypresian) of the Sables à Unios

566 et Térédines Formation (France). The deep secondary sulcus nearly disappears, and the main

567 sulcus borders are virtually fused at the suture of the maxillae in T. stiriacus Peters, 1855

568 (sensu Broin, 1977) from the lower-middle Miocene of Artenay (France). In the living

569 Trionyx triunguis there is no double sulcus, thus resulting in a single sulcus in the same

570 shallow V-shaped section. The section is also shallow V-shaped in T. silvestris and T.

571 michauxi (Broin, 1977; Walker and Moody, 1974), contrasting with the more concave in U

572 sulcus in the Paleocene form from Mont de Berru. A sulcus in $\mathrm{U}$ is present in Trionyx 
573 ikoviensis Danilov et al., 2011, from the middle Eocene of Ukraine, perhaps closer to that of 574 the indefined species from the Mont de Berru and Avenay than to T. michauxi, the other skull 575 parameters being those of Trionyx s.l. The different species of this clade also differ in the 576 palatal width, with a possible dilatation of the maxillae and lower jaw triturating surfaces 577 (characters also variable in living species, as seen in the maxillary dilatation of Pelodiscus 578 sinensis (Wiegman, 1834) specimens in Heude, 1880 and of T. triunguis in Villiers, 1958), 579 and in the correlated coronoid process height. The symphysis of the lower jaw of the different Trionyx s.l. representatives may differ in the presence of a medial weak crest, a short sulcus, a

581 flat surface of the symphysis (its length being related with the palate length), and small variable skull dimensions in the frame of the Trionyx s.l. features given above. Dilated palates exist in the Eocene to Miocene species mentioned above. Due to the absence of the palatal region, the presence of this structure cannot be checked in other European species such as the German T. messelianus Reinach, 1900 from the middle Eocene (early Lutetian) of Messel (see below), and the Italian T. capellinii Negri, 1892, from the same Eocene level of Monte Bolca, their ventral palatal face not being preserved, although the preserved dorsal skull characters are compatible with those of Trionyx with a slender snout that is apparently without palatal dilatation.

Rafetus differs from Trionyx s.l. because it has a much wider skull snout that is rounded more anteriorly. Its palate has a larger foramen intermaxillare and choanae; a shorter space between this foramen and the choanae; a wider and concave sulcus palatinus, with posteriorly diverging borders that are not anteriorly parallel; and an exposed vomer between the not completely joined maxillae posterior to the foramen intermaxillare (Broin, 1977, fig. 67a). The skull of T. henrici Owen, 1849 in Owen and Bell, 1949 (type species of "Rafetoides henrici” in Karl, 1998) and the ventral face of that of T. messelianus (type species of Palaeoamyda Cadena, 2006) (the specimens of which are covered by the hyoid apparatus) are 
598

599

600

601

602

603

604

605

606

607

608

609

610

611

612

613

614

615

616

617

618

619

620

621

622

unknown. Therefore, the generic distinction between all these European species is not correctly justified, and the attribution of all of them to Trionyx s.l. is supported here, justified by the shell features exposed in the main text for the Trionyx specimen from the Osona county.

\section{S3 - New data on several European middle Eocene and Oligocene Pelomedusoides from} the Mediterranean area to be compared with Eocenochelus farresi and Cordichelys sp. from the Osona County.

S3(1) - The Spanish Eocene “Thalassochelys caretta” Faura y Sans, 1915.

The single Spanish specimen attributed to "Thalassochelys caretta” (Fig. 14 (c)) is recognized here as an undefined Bothremydidae, and, therefore, identified as a pleurodiran taxon different from the Taradell podocnemidid Cordichelys specimen. This specimen, currently considered as lost, was found in a middle Eocene (Lutetian) outcrop of the area of Montjuich (Gerona province). It consisted of a dorsal carapace (Fig. 14 (c1) (c2)), figured and analyzed by Faura y Sans (1915), who named it under the name of the living cheloniid species Thalassochelys caretta (actually a junior synonym of Caretta caretta Linnaeus, 1758). The specimen is preserved by the inner face of the carapace. The length of the preserved area is 50 $\mathrm{cm}$, and that of the complete carapace is estimated as close to $55 \mathrm{~cm}$. This carapace is rather narrow for its length. Most part of the left lateral border is not preserved. The limits between most peripherals of the right side cannot be recognized. Several characters allow us to refute its attribution to Cheloniidae (see the cheloniid part): medially, the nuchal is long and relatively narrow, especially at its anterior margin; peripherals 1 and 2 are not elbowed, and they are long (medio-distally); there is no longitudinal mark for the a cheloniid knob for the eighth cervical vertebra, below the nuchal (well-developed in the specimen of Eochelone brabantica in Fig. 9 (b), in Osonachelus decorata (Fig. 10 (f3)) and also in the Cheloniidae 
from Avesa MCSN V2342, described above); the lateroanterior carapace border is slightly rounded, with a slightly prominent nuchal border; the longer region of costal 1 is the medial part. In addition, the anteromedial border of each costal 1 is sutured to the posterolateral border of the narrow nuchal. Costal 1 has a concave anteromedial border and a concave anterolateral border which suture with the posterior border of the long (medio-distally) peripherals 1 and 2, respectively (the second plate being slightly exteriorly displaced). This costal also has anterolateral and lateroposterior borders for the sutures with the long peripherals 3 and 4 (partly), respectively. In Cheloniids, costal 1 has only a wide and single anterior border, sutured with the wide nuchal, and an inclined lateral border contacting both the short (or narrow, i.e. proximo-distally) peripherals 2 and 3, and the completely (in Toxochelyids s.l.) or partial (in Puppigerus) posteromedial border of the peripheral 4 (peripherals which are narrow medio-distally), when the lateral carapace fontanelle is resorbed. This also happens in relatively old living species. If the lateral fontanelle is slightly resorbed, but still anteriorly expanded, the nuchal joins a part of peripheral 1 (e.g., in Rupelchelys Karl and Tichy, 1999, and in some living species in individuals still retaining a moderate lateral fontanelle). In Paleogene Cheloniids with a fully retained lateral fontanelle, costal 1 does not contact any peripheral (e.g., Osonachelus, Eochelone, Argillochelys antiqua, as in relatively young individuals of the living species). Here, there is no mark of any fontanelle in an advanced age, as in Puppigerus, but the peripherals adjacent to costals are wide (medio-distally) and not narrow as in Cheloniids. A mark corresponding to the presence of plastral buttresses is observed in the costals 1 of the specimen of " $T$. caretta" from Montjuich. This contrasts with the Cheloniidae where there is no contact of the barely elevated and not expanded plastral processes with the carapace (i.e., the nearly flat lateral plastral processes have free extremities ending medial to the peripheral border). Right costal 1 of the Montjuich specimen presents a left axillary buttress scar, in a tear-drop shape, and the 
648 left one shows a crushed zone at the place of the axillary buttress scar. The right peripheral 649 border, lateroposteriorly preserved, is firmly sutured to the costals, without any evidence of 650 contact of any free thoracic rib to corresponding peripherals. This contrasts with the

651 Cheloniidae, which generally show a roundly notched medial border of the peripherals, 652 corresponding to a free rib insertion by juxtaposition and not by suture (i.g. Puppigerus 653 camperi in Moody, 1974, pl. 7). The iliac suture is located on costals 6 to 8 as is evidenced by 654 a crushed area. Both the strong axillary buttresses that crush costals 1 and crushing of the

655

656

657

658

659

660

661

662

663

664

665

666

667

668

669

670

671

672 pelvis are very frequent in pleurodiran turtles when they are post mortem flattened by the fossilization process. The pelvis is a rigid elevated block sutured to the carapace and plastron in pleurodiran turtles. A buttress crushing also occurs in other clades, such as the geoemydines, where the pelvis is only linked to the shell, but firmly supported by solid ligaments. This is never the case in the lower pelvis of the Cheloniidae, being low and loosely supported. The attribution of the specimen from Montjuich to Pleurodira is confirmed by another character: the posteriorly interrupted neural series, composed of six neurals, the last being pentagonal. Thus, the neurals of this individual are separated from its single triangular suprapygal by costals 6 to 8 (as in the Taradell specimen and Eocenochelus). This plate has a wide suture with the pygal and right peripheral 11 . By constrast, two to three suprapygals, of different shape, are in contact with both the neural series and the pygal in the case of most of the Cheloniidae (see above, in the cheloniid part). Faura y Sans (1915) figured the specimen with 13 pairs of "marginals" (referring to the peripherals), mentioning the presence of at least 10 to 13 pairs (by comparison with the erroneous interpretation of "25 pairs” (sic) in living Chelonia, a taxon in which only 11 pairs are present), and not excluding the possibility of having more pairs by comparison with the putative "27 pairs” (sic) of living Caretta (actually a taxon with 12 pairs). Those high numbers of pairs recognized by Faura y Sans (1915) in living forms can be explained by the addition of the preserved sulci limits between the 
marginal scutes and the preserved sutural contacts between the peripheral plates. In fact, the preservation does not allow the observation of the real number of peripherals and marginals (the scutes not being preserved in the inner print). Neural 1 of the carapace of Montjuich is ovorectangular, posteriorly narrower than anteriorly, and the hexagonal neurals 2 to 5 (with short lateroanterior sides) are narrow, with particularly narrow anterior and posterior sides, in relation to their width at the adjacent costals junction. This neural morphology is compatible with that of the living cheloniid Caretta, which together with the presence of supernumerary peripherals (here pretended as present in the fossil) could have influenced the determination by Faura y Sans (1915). Besides, in this sense, the neural series of some specimens of living Caretta and Lepidochelys can be interrupted in some regions in the series (Zangerl, 1958). But in these two living Cheloniidae, the series is interrupted by the medial contact of right and left costal of some pairs, posterior to a rhombic or pentagonal reduced neural, and the series may also be posteriorly interrupted anterior to the first suprapygal of the two to three suprapygals present in Cheloniidae, instead of only one in Tertiary pleurodiran turtles as in the Montjuich form. The strong narrowing of each neural plate, anteriorly and posteriorly, is unknown in Podocnemididae, although some species have narrower neurals than in other species, as seen above (for example Eocenochelus eremberti and E. farresi (Fig. 14(a)). A neural narrowing occurs in some Bothremydidae, such as the holotype of Palaeaspis conybearii Owen, 1849, sensu Williams 1954 (see main text) (i.e “Platemys bowerbanki” Owen 1842a, (Owen 1842b), and synonym between others of Emys delabechii Bell, 1849 in Owen and Bell, 1849, but not of Dacochelys delabechei in Lydekker, 1889b). But the narrowing is stronger in the specimen from Montjuich than in most of the representatives of this family. A similar strong neural narrowing is known in some bothremydid members of the Taphrosphys group (Bergounioux, 1956), in Kurmademys (in Gaffney et al., 2006) and in Carteremys leithii (Carter, 1852) (in Williams, 1953). This last species, from the Maastrichtian 
Intertrappean beds of Bombay (Mumbai, India), previously considered by Williams (1953) as a pelomedusid (but having been compared to "pelomedusid” taxa now placed in Bothremydidae), was attributed to Bothremydidae by Lapparent de Broin et al. (2009) (see also Lapparent de Broin and Prasad, submitted). This neural feature is also present in the Greek late Miocene Nostimochelone lampra Georgalis et al., 2013a, interpreted as belonging to an undefined family within Podocnemidoidea. This form, with also a long and narrow costal disk, is similar to the specimen from Montjuich, considering the shape of the carapace elements. However, the carapace of this Spanish specimen seems to be longer posteriorly. The attribution of Nostimochelone to a Bothremydidae instead of a Podocnemididae is supported here. Beside the very narrow neurals, more characteristic of some Bothremydidae than of Podocnemididae, it has a moderate length of costal 1 that primitively occurs in some Bothremydidae such as Bothremydinae and Arenila Lapparent de Broin and Werner, 1998, a length particularly moderate in relation to Neochelys (Fig. 14(b)), as far as Tertiary species are concerned. Anyway, by its characters, the specimen from Montjuich is a pleurodire and it is attributed here to Bothremydidae rather than to Podocnemididae, and its attribution to a cryptodire Cheloniidae is refuted. It differs radically from the Taradell carapace attributed to the pleurodire Cordichelys, especially for the particularly wide and rounded shape and the shorter and wider neurals of this form. Considering the limited information available, the Bothremydidae from Montjuich remains as an indefined genus and species among the family. S3(2) - The Eocene Pelomedusoides from Avesa (Verona, Northern Italy).

Three pleurodiran taxa, apart from a Cheloniidae (see above), are identified in the locality of Avesa. At least one of them corresponds to a Bothremydidae, which was mentioned and figured by Broin (1977). They were found in marine-littoral levels. The middle Eocene age (ca. middle Lutetian) of the level is approximately equivalent to that of Taradell, being slightly younger than the lacustrine locality of Monte Bolca (close to the lower-middle 
723 Eocene limit i.e., the Ypresian-Lutetian boundary), characterized by its famous fauna of fishes, and being the type locality of the podocnemidid Neochelys capellini (Zigno, 1889). It is also stratigraphically close to the middle Lutetian Cava Valle locality, were Neochelys nicolisii (Zigno, 1890) was defined (see Broin, 1977). The fossils from Avesa studied here correspond to several indetermined pleurodiran specimens, including at least a member of the Bothremydidae (which shares characters with the large and medioanteriorly elongated bothremydid forms), an indetermined Podocnemidoidea, and a pleurodiran form compatible with Cordichelys.

(a) Avesa Bothremydidae indet, MSNV V2386-V 2387. The specimen was attributed to Taphrosphys sp. by Broin (1977) and positioned in the Pelomedusidae (s.l.) when the family Bothremydidae had not yet been readmitted as an individualized family. Before that study, the family Bothremydidae (originally proposed by Baur, 1891) had been supported by some authors. Hay (1908) attributed Taphrosphys to that group, and Nopca (1931a,b) recognized Elochelys as a "Bothremydidae” (Nopcsa,, 1931a, p.1) and perhaps Polysternon also [“Polysternum pourrait donc aussi être une Bothremyide”, Nopcsa 1931b, p. 231]. Gaffney (1975) identified the Bothremydidae as composing only a subfamily within Pelomedusidae. This was subsequently accepted by Broin (1977). However, the family Bothremydidae was redefined by Broin (in Antunes and Broin, 1988) based on skull characters. The Avesa specimen V 2386-V2387 corresponds to a fragment of an elongated carapace of a specimen probably reaching a length of $60 \mathrm{~cm}$. The medial region of the carapace, extending from the anterior carapace border to the partial neurals and costals 5, preserves the bones in inner view posteriorly on the fragment, and only the external imprint of the more anterior bones ( $\mathrm{V}$ 2386). The whole specimen is preserved as an imprint of the inner face of the elements in the counter-slab, together with the bony remains of the axillary buttress, vertebral neural arches and rib apophyses (V2387). The specimen was described and partly figured (V2386) by Broin 
(1977, pl. 1, fig. 8). The anterior carapace border is rounded, at least at the level of peripherals 1 and the nuchal. It shows an elongated (partially preserved) nuchal that is anteriorly narrow, with a long dorsal overlap of marginals 1 (but a short inner overlap), long adjacent anterior peripherals, and an elongated costal 1 (which is almost as long as wide). Ventrally, the axillary buttress extemity is visible on V2387, coming through costal 1 as a sectioned ovoid bony remain, and, after getting thinner, it follows at the limit between the peripherals 2 and 3 . The neurals are narrow and long. The first neural is quadrangular, with convex borders. The two following neurals are hexagonal, with anterolateral sides which are particularly long for the considerable neural length. The second is anteriorly wider than the third, being a little wider anteriorly than posteriorly, at the contact with costals 1 and 2 . The third is nearly costantly wide except for being wider at its short pinched angles between the costals 2 and 3 . All the carapace elements are longer than those of the Montjuich bothremydid specimen. There is no decoration in the imprint of the anterior external part. It has been attributed to Taphrosphys (type species T. sulcatus Leidy, 1856) (Gaffney, 1975), because of the relative proportions of the elements, and in the state of knowledge of the family at that time. But in the absence of the characteritic decoration, it can also be compared to the Foxemydina. No species of this clade presents such neural morphology and such axillary buttress morphology, and it seems to represent a new form, the closest being Polysternon provinciale from Villeveyrac and the indetermined Bothremydidae from the Oligocene of Montoulieu (see below), so that it could be interpreted as a member of an informal “Polysternon group”. The information seems to us too limited to allow us the erection of a new genus and species. Anyway, this indetermined bothremydid turtle differs from the podocnemidid Cordichelys sp. specimen from Taradell, studied in this paper, as well as from the specimen of Monjuich. (b) Avesa Podocnemidoidea indet., MSNV V2343, V2342-V2345, V2347 (See their comparative description in Broin, 1977). 
773 The partial carapace MSNV V2343 corresponds to a more rounded specimen than the

774

775

776

777

778

779

780

781

782

783

784

785

786

787 previously discussed putative member of a "Polysternon group". The length of this carapace is close to $30 \mathrm{~cm}$. It lacks most parts of the plates, but they are recognized in the external cast. The anteromedial region is poorly preserved. The costals 2 to 6 are preserved, as well as the plates corresponding to the lateroposterior region. As in all the Pelomedusoides from Avesa examined here, the neural series, composed of six neurals, is separated from the single suprapygal. MSNV V2343 shows the partial pleurodiran scar in the natural cast, corresponding to the medial part of the axillary buttresses, under costals 1 . The scar of the ilia for its suture with the carapace is recognized by the crushed parts of costals 7 to 8 . A rare peculiarity of this specimen is the externally pointed posterior peripherals, at the limit of the marginal scutes. This character is shared with Neochelys arenarum Broin, 1977 and other Neochelys specimens. In fact, as indicated, the age of this Avesa site is close to that of the type localities (that are continental when Avesa in marine-littoral) of the Italian species Neochelys nicolisii and N. capellini (see Broin, 1977). The latter lacks external peripheral points. However, if the crushing of costals 7 to 8 corresponds to the scar of the ilium, the extension of this scar on costal 8 is a primitive character state, recognized for the Bothremydidae and Cretaceous Podocnemididae but not for the Cenozoic Podocnemididae. However, the mark of the crushing zone could be greater than the real iliac scar surface. In that case its attribution to Neochelys would also be possible because a freshwater form might have been carried along in the littoral waters of the Avesa area. This carapace lengh to width relationship is comparable to that of a Neochelys or of various Bothremydidae, but it is clearly different from the wide and short carapace of Cordichelys sp. Specimen MSNV V2347 could belong to the same form. Thus, the preserved lateral and posterior parts of its carapace are identical to those of MSNV V2343. Vertebrals 2 to 5 are preserved, although V2 and V3 are only known from their lateral regions. As in several bothremydid taxa, the vertebral series is 
narrow. This character is also shared with Neochelys, a taxon with substraight vertebral borders, except at the pinched part between the adjacent pleurals. Anyway, the Taradell specimen attributed to Cordichelys is also different from this individual by its particularly rounded and shorter carapace.

\section{(c) Avesa Podocnemidoidea indet.,?cf. Cordichelys sp.. Specimen MSNV V2388 is an} internal cast of the posterior half of a carapace, corresponding to the area occupied by costals 3 to the last pair, and with the left lateral peripheral border. The carapace was wide in relation to its length. The preserved width is of $19 \mathrm{~cm}$ at the vertebrals V3-V4 union level, the complete carapace width in that region can be estimated as around $24 \mathrm{~cm}$; the distance between the anterior part of V3 and posterior part of V5 is $12 \mathrm{~cm}$; the width of V3 is $7.2 \mathrm{~cm}$ and its length is $4.4 \mathrm{~cm}$; the width of V4 is $6.2 \mathrm{~cm}$ and its length is $4.3 \mathrm{~cm}$; the length of the pleural 3-pleural 4 sulcus is $3.6 \mathrm{~cm}$. The costal disk was cordiform, posteriorly being strongly narrowed as in Cordichelys antiqua (Andrews, 1903), and in the reconstructed shell for the specimen from Taradell. The sulci of the pleurals adjacent to vertebrals 3 and 4 are preserved. These scutes are extremely short relative to their width. The lateral borders of the vertebrals are convex while the posterior ones being concave. All these features are compatible with those of the podocnemidid Cordichelys sp., from Taradell, with a similar stratigraphical age. MSNV V2388 differs from the previous specimen MSNV V2347 (identical to MSNV V2343, as explained above) in its widest carapace and cordiform disk, and its widest and shortest vertebrals. The convexity and concavity of the vertebral borders are also present in other Pelomedusoides such as the bothremydid Palaeaspis sensu Williams, 1953 (seen in the holotype of Emys delabechii Bell, 1849 in Owen 1849-1884, pl. 37). But these vertebrals are much longer relative to their width, located in a relatively narrower carapace as in most Neochelys spp., the Avesa specimen MSNV V2347, and other Pelomedusoides than Cordichelys. For example, the holotype of $N$. arenarum Broin, 1977 has relatively wide 
vertebrals 2 and 3 relative to their length (with irregular borders), but in a relatively much narrower carapace than in MSNV V2388 and not being cordiform. Therefore, MSNV V2388 cannot be attributed to the genus Neochelys, and no defined bothremydid species is compatible with it. Based on the limited information on about this specimen, it remains as indeterminate but compatible with the podocnemidid Cordichelys from Taradell.

Consequently, three pleurodiran representatives are identified in Avesa, two of them being clearly different from the podocnemidid Cordichelys sp. from Taradell and Eocenochelus from Can Beulovi, but also from the indetermined bothremydid "Thalassochelys caretta" from Montjuich. One of them is recognized as an indetermined bothremydid, possibly related to a "Polysternon group". Another is an indetermined Podocnemidoid (Bothremydidae or Podocnemididae) and the third of these three forms is compatible with the podocnemidid Cordichelys. An indetermined cheloniid is also identified in this locality (Broin, 1977). It is different from the two forms identified in the Osona county: Eochelone and Osonachelus. S3(3) - The French Oligocene "Chrysemys” montolivensis Roman, 1897 In addition to the previously discussed forms, another European Paleogene specimen was proposed as a bothremydid without providing arguments to justify that attribution (Lapparent de Broin and Werner, 1998; Lapparent de Broin, 2001). It is the French “Chrysemys” montolivensis. Its holotype and only known specimen comes from the Oligocene (Rupelian) of Montoulieu (Broin, 1977). Therefore, its age is just younger than that of the Osona pleurodire Eocenochelus (latest Eocene, Priabonian) but clearly younger than the other Osona pleurodire Cordichelys sp., from the Lutetian of the Tavertet Limestones Formation and than the Montjuich bothremydid. The carapace and plastron (Broin, 1977, fig. 66; pl. 1, fig. 5) resemble to those of the specimen of the late Cretaceous bothremydid Polysternon provinciale from Villeveyrac (Hérault, France), figured in Buffetaut et al. (1996) (private coll. Costa, in parts newly prepared at the MNHN), as well as the $P$. provinciale new material 
preserved in Montpellier University, and that figured in other publications and including the type material (Broin, 1977; Lapparent de Broin and Murelaga, 1999; Lapparent de Broin, 2001; Nopcsa, 1931b). Although smaller than Polysternon provinciale (the length of "Chrysemys" montolivensis being of $33 \mathrm{~cm}$, and that of the specimen from Villeveyrac of 51 $\mathrm{cm}$ ), the carapace of both forms is ovorectangular. It can be recognized as a Pelomedusoides by the presence of seven neurals, costals 6 to 8 crushed by the ilia, lateral rounded mesoplastra, and sutures of the pelvis on the xiphiplastra. It can be considered as a Bothremydid morphologically close to the Villeveyrac Polysternon specimen, not only by the shell shape, but also considering other characters: elongated anterior elements of the carapace (both costals 1, crushed by the axillary buttresses, as peripherals 2 and 3, allowing to interpret the missing nuchal as elongated); slight decoration by a fine striation on the area covered by the vertebrals and pleurals that is also visible on several plastral regions (on the mesoplastra); wide plastron with wide lobes filling the axillary and inguinal openings (with a slightly wider and a little more rounded posterior lobe than in P. provinciale); posterior lobe with lateral borders anteriorly curved, medially parallel, and rounded posteriorly (from the hypoxiphiplastral suture up to the anal point) with a narrow but as long as wide anal notch (slightly shorter and narrower than in P. provinciale); humero-pectoral sulcus crossing the posterior half of the entoplastron, laterally reaching the epi-hyoplastral suture; convex pectoroabdominal sulcus that is laterally located on the anterior extremity of the mesoplastron; and small pelvic scars identical to those of Polysternon, particularly to those of the specimens from Fons 0 - Champs Garrimond and Villeveyrac (southwestern France): the pubic scar is a short narrow lens, and the ischiatic scar is a small triangle medially elongated by a fine transversal line as in P. provinciale specimens (Broin, 1977: figs. 2 from Valdonne, fig. 3 and pl. 1, fig. 6 from Fons 0 - Champs Garrimond, compared to the scars of "Ch.” montolivensis in Broin (1977), fig. 66, and pl. 1, fig. 5). This form is a Bothremydidae but not related to the 
873 Lutetian bothremydid "Thalassochelys caretta" from Montjuich and neither related to the

874 Priabonian Podocnemididae from the Osona county, Eocenochelus farresi and the Lutetian 875 podocnemidid Cordichelys sp.

\section{S3(4) - Supplementary Medirerranean Cenozoic pleurodires}

877 With the exception of “C.” montolivensis, the European post-Eocene record of Pleurodira is 878 limited to scarce remains, which do not allow a precise systematic attribution. Some of them 879 probably represent new dispersal events from Africa (Broin, 1977; Pérez-García and Lapparent de Broin, 2014). The attribution at the family level has been speculated for some

881

882 remains such as the Greek Nostimochelone (above evocated in comparison with the Montjuich form) (Georgalis et al., 2013 a, b), and the Maltese Miocene “Podocnemis” lata Ristori, 1894, attributed to Bothremydidae by Lapparent de Broin and Werner (1998). The available evidence shows that Bothremydidae persisted at leat during the Miocene in the Mediterranean-northern Africa platform area. In this way, this clade has been identified in the Miocene of Oman, by specimens including isolated shell plates, a femur and a skull of a Podocnemidoidea (by the quadrate sutured to the basisphenoid and the basioccipital), and that is Bothremydid (by the separated columella auris and Eustachian tube, absence of an enlarged carotid canal in the podocnemidoid fossa and of the pterygoid wings of the Podocnemididae) (Roger et al., 1994). The Bothremydidae are also present in the Miocene of Saudi Arabia, being represented by plates and vertebrae given as "Pelomedusidae... undetermined remains" by Thomas et al. (1982) (Lapparent de Broin, 2000; Lapparent de Broin et al., 2009; Lapparent de Broin and Prasad submitted). However, none of the genera of Pleurodira recognized in the Osona County in Catalonia, i.e. the podocnemidid Eocenochelus and Cordichelys, are known after the Eocene-Oligocene limit. 


\section{Supplement references, supplementary to main text}

899

900

Danilov, I. G., Zvonok, E.A, Syromyatnikova, E.V. and Udovichenko N.I.: A new species of

901 soft-shelled turtle (Trionychidae) from the middle Eocene of Ukraine, Proc. Zool. Inst.

902 RAS, 315(4), 399-411, 2011.

903

Peters, K. F.: Schildkrotenreste aus den osterreichischen Tertiarablagerungen, Denkschr.

904 Akad. Wiss. Wien, Math. natur. Kl., 9, 22 pp., 1855.

905

Thomas, H., Sen, S., Khan, M., Battail, B., and Ligabue, G. C.: The Lower Miocene Fauna of 906 Al-Sarrar (Eastern Province, Saudi Arabia), Jour. Saudiarab. Arch., 5, 109-136, 1982.

Walker, C. A. and Moooy, R. T. J.: A new trionychid turtle from the Lower Eocene. of Kent. 908 Palaeontology, 17 (4), 901—907, 1974.

909 Wiegmann, A. F. A.: Beiträge zur Zoologie gesammelt auf einer Reise um die Erde. Abh. 6, 910 Amphibien, Nova Acta Physico-Medica, Academiae Caesarae Leopoldino-Carolinae, 911 Halle, 17, 185-268, 1835. Wiegmann, A. F. A.: Beiträge zur Zoologie gesammelt auf einer 912 Reise um die Erde. Abh. 6, Amphibien, Nova Acta Physico-Medica, Academiae Caesarae 913 Leopoldino-Carolinae, Halle, 1834, 17, 185—268, 1835. 